\title{
Denitrification in the rhizosphere of the two seagrasses Thalassia hemprichii (Ehrenb.) Aschers and Halodule uninervis (Forsk.) Aschers
}

\author{
W.Y. Shieh*, J.T. Yang \\ Institute of Oceanography, National Taiwan University, P.O. Box 23-13, Taipei, Taiwan
}

Received 31 July 1996; received in revised form 5 February 1997; accepted 13 March 1997

\begin{abstract}
This work examined the denitrification in the rhizosphere (rhizome-root complex with attached sediment) and rhizoplane (rhizome-root complex) of the two seagrass species Thalassia hemprichii and Halodule uninervis, as well as that in the nonrhizosphere sediment and seawater, by the acetylene blockage technique. The samples were collected from a seagrass bed in Nanwan Bay, Kenting National Park, Taiwan. Most of the rhizoplane and rhizosphere samples (25 out of 31 for $T$. hemprichii and 26 out of 29 for $H$. uninervis) exhibited detectable levels of denitrifying $\left(\mathrm{N}_{2} \mathrm{O}\right.$-producing) activity within $12 \mathrm{~h}$ of aerobic or anaerobic incubation $\left(0.3\right.$ to $2.2 \mu \mathrm{mol} \mathrm{N}_{2} \mathrm{O} \cdot \mathrm{g}$ wet $\mathrm{wt}^{-1} \cdot \mathrm{h}^{-1}$ ); however, this was undetected in the nonrhizosphere sediment and seawater samples. Insufficiency of nitrate or organic matter would be apt to restrict the magnitude of in situ denitrification in the seagrass rhizosphere including rhizoplane. Most-probable-number values of denitrifying bacteria in the rhizosphere and rhizoplane ( 29 out of 32 counting values between $10^{3}$ and $10^{4}$ cells $\cdot g$ wet $\mathrm{wt}^{-1}$ ) in nearly all cases were significantly greater than those in the nonrhizosphere sediment (seven out of ten counting values lower than $10^{3}$ cells $\cdot g$ wet $\mathrm{wt}^{-1}$ ) and seawater $\left(<10^{1}\right.$ cells $\left.\cdot \mathrm{ml}^{-1}\right)$. Eighty-five strains of denitrifying bacteria in total were isolated from the rhizosphere, rhizoplane and nonrhizosphere samples. Only 35 strains among them did not lose their denitrifying ability after subculture, the majority of which were motile, slightly to moderately halophilic, Gram-negative rods. (C) 1997 Elsevier Science B.V.
\end{abstract}

Keywords: Denitrification; Denitrifying bacteria; Acetylene blockage technique; Seagrass rhizosphere; Seagrass rhizoplane; Thalassia hemprichii; Halodule uninervis

\footnotetext{
*Corresponding author. Fax: 88623626092.
} 


\section{Introduction}

Denitrification, the dissimilatory reduction of nitrate $\left(\mathrm{NO}_{3}^{-}\right)$or nitrite $\left(\mathrm{NO}_{2}^{-}\right)$to the gaseous end product(s) nitrous oxide $\left(\mathrm{N}_{2} \mathrm{O}\right)$ or dinitrogen gas $\left(\mathrm{N}_{2}\right)$, is carried out by many heterotrophic bacteria which are essentially facultative anaerobes. Denitrifying bacteria perform this process yielding energy by oxidating organic electron donors with $\mathrm{NO}_{3}^{-}$or $\mathrm{NO}_{2}^{-}$as ultimate electron acceptor(s) (Knowles, 1982). The magnitude of the loss of fixed nitrogen via denitrification in marine systems is of extensive interest because nitrogen is frequently a limiting nutrient for primary production in such systems (Nybakken, 1993). The presence of denitrification has been demonstrated in sediments from numerous coastal and estuarine areas. Denitrification rates in these sediments are reported to be in the range from 0 to more than $1000 \mu \mathrm{mol} \mathrm{N} \cdot \mathrm{m}^{-2} \cdot \mathrm{h}^{-1}$, with rates commonly between 50 and $250 \mu \mathrm{mol} \mathrm{N} \cdot \mathrm{m}^{-2} \cdot \mathrm{h}^{-1}$ (Seitzinger, 1988).

Seagrasses are monocots adapted to shallow coastal and estuarine waters of tropical and temperate zones but completely absent in fresh water (den Hartog, 1970; Kuo and McComb, 1989). Seagrass beds have extremely high productivity and contribute significantly toward the total production of inshore waters as they are generally densely covered with plants and cover such extensive areas in shallow coastal environments (Nybakken, 1993). $\mathrm{NO}_{3}^{-}$and $\mathrm{NO}_{2}^{-}$in interstitial waters of nonrhizosphere sediments $(0-25 \mathrm{~cm})$ from some seagrass beds, which may largely diffuse from the rhizosphere zones, were estimated to be nearly ten times greater in concentration than those in overlying waters (Iizumi et al., 1980). Average rates of denitrification in the surface sediments $(0-7 \mathrm{~cm})$ from various stations of these seagrass beds were $7.6 \times 10^{-11}$ to $6.9 \times 10^{-10} \mathrm{~g} \mathrm{~N} \cdot \mathrm{g}$ wet $\mathrm{wt}^{-1} \cdot \mathrm{h}^{-1}$ (converted to $3.5-34.5 \mu \mathrm{mol} \mathrm{N} \cdot \mathrm{m}^{-2} \cdot \mathrm{h}^{-1}$ by Seitzinger (1988)). No reports have demonstrated denitrification in the rhizosphere or rhizoplane of any seagrasses.

A reduced zone that is well developed in the seagrass bed sediments is indicated by a black color together with the odor of hydrogen sulfide except for the top few millimeters of the sediments (Iizumi et al., 1980). As demonstrated previously, an oxygen transport system is present in the seagrass Zostera marina; oxygen evolved within the foliar tissues in association with photosynthesis is transported to rhizomes and roots and released into the rhizosphere sediment (Iizumi et al., 1980; Smith et al., 1984). Nitrification, an essentially aerobic process, can occur in the seagrass rhizosphere surrounded by anoxic sediments owing to the presence of this oxygen transport system (Iizumi et al., 1980; Moriarty and Boon, 1989). An assumption given here is that the seagrass rhizosphere is more favorable than the outside nonrhizosphere sediments for the occurrence of denitrification. This is apparent from considering that the supply of $\mathrm{NO}_{3}^{-}$ or $\mathrm{NO}_{2}^{-}$via nitrification may be limited to the rhizosphere. Moreover, only the denitrifying bacteria distributed in the rhizosphere can directly utilize organic exudates or cell debris of the seagrass rhizome-root complexes as electron donors for denitrification. This study was designed to verify this assumption by selecting a seagrass bed located in Nanwan Bay, Kenting National Park, Taiwan as a study site. Denitrifying bacteria distributed in the seagrass bed were also enumerated, isolated and character ized. 


\section{Materials and methods}

\subsection{Collection and preparation of samples}

Thalassia hemprichii (Ehren.) Aschers and Halodule uninervis (Forsk.) Aschers are two seagrass species found to cohabit in a seagrass bed in Nanwan Bay of Kenting National Park, Taiwan. The seagrasses, the nonrhizosphere surface sediment $(0-10 \mathrm{~cm})$ and the overlying seawater were all collected from the seagrass bed in different months during the years of 1993 and 1994. Assays for denitrification were established within a few hours of sample collection. Rhizoplane (rhizome-root complex) and rhizosphere (rhizoplane with the attached sediment approximately 3-6 $\mathrm{mm}$ radius around the root surface) samples were taken from both of the seagrasses; the rhizoplane samples were obtained by washing the rhizosphere samples three times with sterile $\mathrm{NaCl}$-Tris buffer (30 $\mathrm{g} \mathrm{NaCl}$ and $0.24 \mathrm{~g}$ Tris in 11 of deionized water; $\mathrm{pH} \mathrm{8.0)} \mathrm{to} \mathrm{remove} \mathrm{the} \mathrm{attached}$ sediment.

\subsection{Measurement of denitrification}

Each of the rhizosphere, rhizoplane and nonrhizosphere samples ( $2 \mathrm{ml}$ for seawater and approximately $2 \mathrm{~g}$ wet wt for the other samples) was placed in a $25 \mathrm{ml}$ flask; to each flask was added $2.5 \mathrm{ml}$ of sterile Tris-seawater buffer (20 mM Tris in $80 \%$ seawater, $\mathrm{pH}$ $8.0)$ or the same buffer containing glucose $(10 \mathrm{mM}), \mathrm{NO}_{3}^{-}(10 \mathrm{mM})$, or both. All flasks were sealed with rubber stoppers. Denitrifying $\left(\mathrm{N}_{2} \mathrm{O}\right.$-producing) activity associated with each sample was assayed by the acetylene blockage technique (Balderston et al., 1976; Yoshinari et al., 1977; Sorensen, 1978; van Rattle and Patriquin, 1979) under either aerobic or anaerobic conditions. Anaerobic conditions were established by flushing the flasks for around 5 min with argon (Ar) gas. Incubation was initiated after injecting acetylene $(2.25 \mathrm{ml}$ at $1 \mathrm{~atm}$; ca. $92.2 \mu \mathrm{mol})$ into each flask using a gas-tight syringe. Both aerobic and anaerobic samples were incubated at $25^{\circ} \mathrm{C}$ in the dark. Gas samples $(1.0 \mathrm{ml})$ were taken from each flask using a gas-tight syringe after incubation for $12 \mathrm{~h}$. They were stored in air-tight vials and analyzed later for $\mathrm{N}_{2} \mathrm{O}$ using a gas chromatograph (Shimadzu GC-14A, Kyoto, Japan) equipped with a thermal-conductivity detector (TCD) and with connected columns of Porapak Q and N (Waters, Milford, Massachusetts, USA; both $3 \mathrm{~mm} \times 2 \mathrm{~m}$ ) at $70^{\circ} \mathrm{C}$. Helium $(\mathrm{He})$ functioned as the carrier gas at a flow-rate of $40 \mathrm{ml} \cdot \mathrm{min}^{-1}$.

The acetylene blockage technique was also applied in determining the $\mathrm{N}_{2} \mathrm{O}$-producing activity of the denitrifying isolates. Cells from PY-II agar plates were introduced into tubes $(18 \mathrm{~mm} \times 15 \mathrm{~cm})$ containing PYN broth medium $(5 \mathrm{ml}$; see Section 2.3), and all culture tubes were sealed with rubber stoppers. Acetylene $(2.0 \mathrm{ml}$ at $1 \mathrm{~atm}$; ca. 81.9 $\mu \mathrm{mol})$ was injected into these tubes directly or after replacement of air in the tubes with Ar. Gas samples $(0.5 \mathrm{ml})$ were withdrawn from the tubes for analyzing $\mathrm{N}_{2} \mathrm{O}$ amounts after cultivation for 2 to 4 days at $25^{\circ} \mathrm{C}$ in the dark. 


\subsection{Bacterial media}

Polypepton-yeast (PY) broth medium contained the following (in grams per liter of deionized water): Polypepton (Daigo, Tokyo, Japan), 2.0; Bacto-yeast extract (Difco, Detroit, Michigan, USA), 0.5; $\mathrm{NaCl}, 25.0 ; \mathrm{MgSO}_{4} \cdot 7 \mathrm{H}_{2} \mathrm{O}, 5.0 ; \mathrm{CaCl}_{2}, 0.005$; and Tris, 6.0; it was adjusted to $\mathrm{pH}$ 8.0. PY-II agar medium contained (in grams per liter of $80 \%$ seawater): Polypepton, 2.0; Bacto-yeast extract, 0.5 and Bacto-agar (Difco), 15.0; the medium's $\mathrm{pH}$ was adjusted to 7.6. PY-II stab medium was identical to PY-II agar except that agar was added at $0.3 \%(\mathrm{w} / \mathrm{v})$. PYN broth medium was prepared by adding $\mathrm{KNO}_{3}$ at $0.1 \%(\mathrm{w} / \mathrm{v})$ to PY broth medium.

The medium for glucose fermentation test consisted of two parts: PY broth medium $(10 / 9$ strength, $900 \mathrm{ml})$ supplemented with bromothymol blue $(0.03 \mathrm{~g})$ and glucose solution $(5 \%, 100 \mathrm{ml})$. The two parts were separately autoclaved and mixed after cooling to room temperature. Two modified PY-II agar media containing gelatin (5 $\left.\mathrm{g} \cdot \mathrm{1}^{-1}\right)$ and DNA $\left(2 \mathrm{~g} \cdot \mathrm{1}^{-1}\right)$, respectively, were used for gelatinase and DNAse tests. Media used to determine bacterial ability to grow in $\mathrm{NaCl}$ at various concentrations contained (in grams per liter of deionized water): Bacto-yeast extract, 4.0; $\mathrm{MgSO}_{4}$. $7 \mathrm{H}_{2} \mathrm{O}, 5.0 ; \mathrm{CaCl}_{2}, 0.1$; and $\mathrm{NaCl}, 0-100.0$. They were all adjusted to $\mathrm{pH} 8.0 . \mathrm{HCl}(1.0$ $\mathrm{M})$ or $\mathrm{KOH}(1.0 \mathrm{M})$ were used to adjust the media's $\mathrm{pH}$.

\subsection{Bacterial enumeration}

A $2 \mathrm{~g}$ wet mass of each of the fresh rhizosphere and rhizoplane samples (see Section 2.1) was vigorously shaken in $50 \mathrm{ml}$ of sterile $\mathrm{NaCl}$-Tris buffer containing Tween 80 (2 $\mathrm{ppm}$ ). The shaken solutions (rhizosphere and rhizoplane rinse waters) and the samples of nonrhizosphere sediment and seawater were decimally diluted with the same buffer. Various dilutions of these samples were used for bacterial enumeration.

Portions $(1 \mathrm{ml})$ of the appropriate decimal dilutions of various samples were transferred to rimless tubes containing PYN or PY broth medium $(5 \mathrm{ml}$ ); a Durham insert was placed in an inverted position into each tube of PYN medium. The PYN and PY broth media were used for the most-probable-number (MPN) counts of denitrifying bacteria and heterotrophic bacteria, respectively. All cultures were incubated at $25^{\circ} \mathrm{C}$ in the dark for 14 days aerobically (for counts of both denitrifying bacteria and heterotrophic bacteria) or anaerobically (using anaerobic jars; only for counts of denitrifying bacteria). Gas production (accumulated in Durham inserts) and visible turbidity's development were the respective criteria used for MPN estimation of denitrifying bacteria and heterotrophic bacteria. All MPN values obtained were estimated by the three-tube inoculation method (Shieh et al., 1989).

\subsection{Isolation of denitrifying bacteria}

The MPN cultures considered as positive in denitrifying bacteria were transferred (one loopful) to fresh PYN broth medium $(5 \mathrm{ml}$ ) for a secondary enrichment cultivation. The secondary enrichment cultures with gas production were streaked (one loopful) onto PY-II agar plates, and the plates were incubated at $25^{\circ} \mathrm{C}$ for $3-5$ days under aerobic or 
anaerobic conditions. Colonies of 1-3 predominant types appearing on each plate were collected and purified by successive streaking on PY-II agar plates. All the isolates that again produced gas in PYN broth were kept in PY-II stab medium at $20^{\circ} \mathrm{C}$ and subcultured at intervals of $2-3$ months.

\subsection{Characterization and grouping of denitrifying isolates}

Only the stock cultures not losing $\mathrm{N}_{2} \mathrm{O}$-producing ability were subjected to further characterization according to the methods previously described (Shieh et al., 1988) and a test cited below. Flagellar arrangement of the cells of each isolate was examined by transmission electron microscopy. The cells, growing for 2 to 3 days, were fixed with $3 \%$ glutaraldehyde and negatively stained with potassium phosphotungstate $(1 \%, \mathrm{w} / \mathrm{v}$, $\mathrm{pH} 7.0)$.

\section{Results and discussion}

\subsection{Denitrification associated with the seagrass rhizosphere and rhizoplane}

Fig. 1 depicts denitrification by the rhizosphere and rhizoplane samples of $T$. hemprichii and $H$. uninervis supplemented with neither $\mathrm{NO}_{3}^{-}$nor glucose. The majority of these rhizosphere and rhizoplane samples (25 out of 31 for $T$. hemprichii and 26 out of 29 for $H$. uninervis) exhibited detectable levels of denitrifying activity within $12 \mathrm{~h}$ of aerobic or anaerobic incubation $\left(0.3-2.2 \mu \mathrm{mol} \mathrm{N}_{2} \mathrm{O} \cdot \mathrm{g}\right.$ wet $\left.\mathrm{wt}^{-1} \cdot \mathrm{h}^{-1}\right)$. Detecting any denitrifying activity from these rhizosphere and rhizoplane samples indicated the coexistence of denitrifying bacteria with either or both of $\mathrm{NO}_{3}^{-}$and $\mathrm{NO}_{2}^{-}$. Little of the activity could be due to proliferation of denitrifying bacteria since the bacterial counts as in MPN values did not show any significant increases up to $12 \mathrm{~h}$ of incubation (data not shown). No detectable activity was observed in any unsupplemented samples of nonrhizosphere sediment and seawater (data not shown). Our data have supported the assumption that the seagrass rhizosphere is more favorable than the outside nonrhizosphere sediments for the denitrification. Denitrification rates estimated by the ${ }^{15} \mathrm{~N}$ tracer technique in the nonrhizosphere sediments $(0-25 \mathrm{~cm})$ from a bed of the seagrass Z. marina in Izembek Lagoon, Alaska, were in a range between $4.9 \times 10^{-11}$ and $1.2 \times 10^{-9} \mathrm{~g} \mathrm{~N} \cdot \mathrm{g}$ wet $\mathrm{wt}^{-1} \cdot \mathrm{h}^{-1}$ (Iizumi et al., 1980). Such low levels of activity were not recorded in the present study because the gas chromatography system used in this study could only detect $\mathrm{N}_{2} \mathrm{O}$ at a concentration exceeding $1000 \mathrm{ppm}\left(0.03 \mu \mathrm{mol} \mathrm{N} \mathrm{N}_{2} \mathrm{O} \cdot \mathrm{g}\right.$ wet $\mathrm{wt}^{-1} \cdot \mathrm{h}^{-1}$, or $8.4 \times 10^{-7} \mathrm{~g} \mathrm{~N} \cdot \mathrm{g}_{\text {wet }} \mathrm{wt}^{-1} \cdot \mathrm{h}^{-1}$ ).

Denitrification in association with the rhizosphere did not significantly differ from that associated with the rhizoplane (Fig. 1); respective ratios of the average denitrification rates of $T$. hemprichii rhizosphere to $T$. hemprichii rhizoplane and $H$. uninervis rhizosphere to $H$. uninervis rhizoplane were 0.7 to 0.8 and 1.0 to 1.2 under aerobic conditions, and 0.4 to 0.5 and 0.7 to 1.0 under anaerobic conditions. Denitrifying activity associated with the attached sediment in most cases was probably detectable, but lower than that associated with the rhizoplane. 

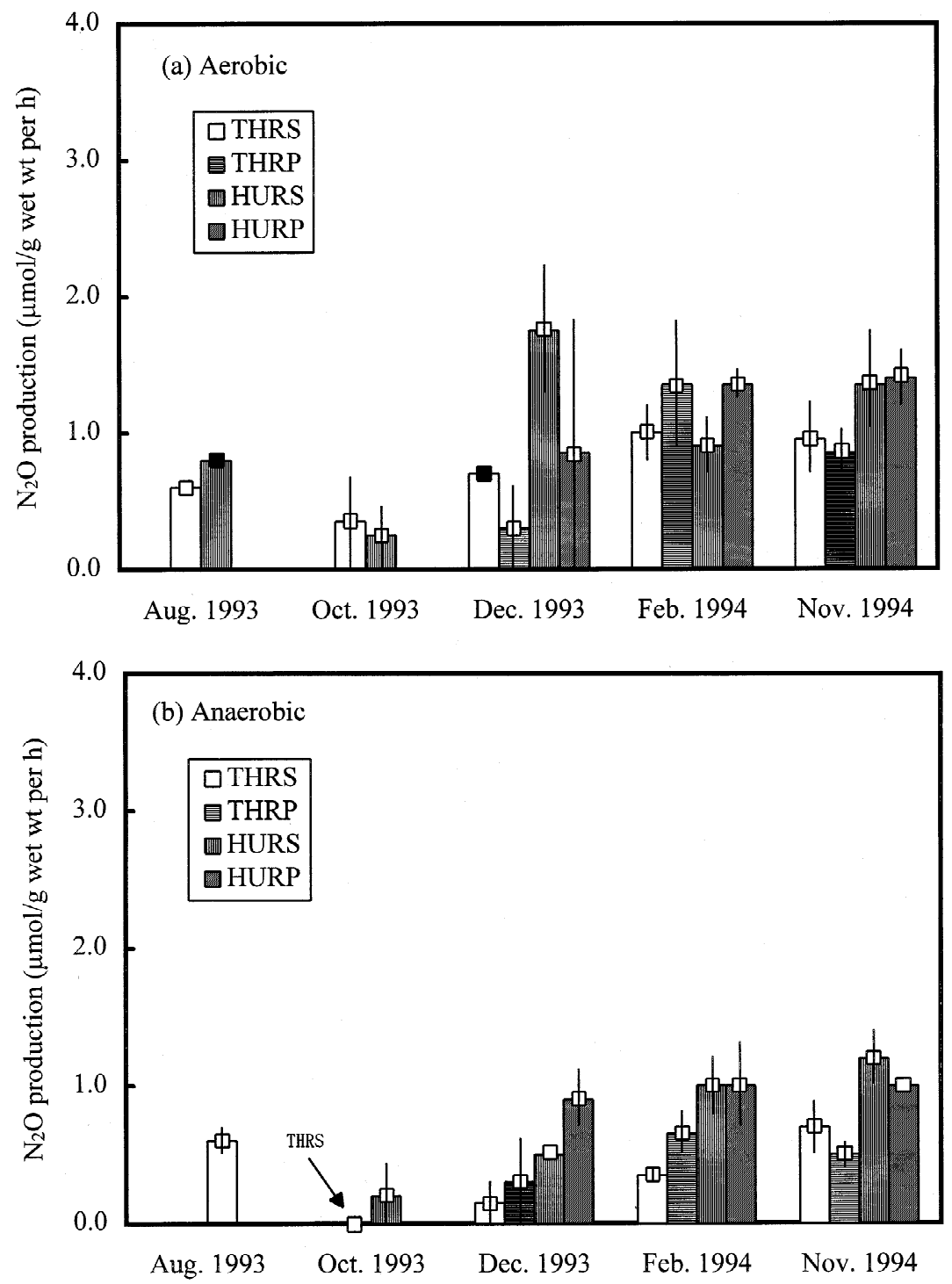

Fig. 1. Denitrification by the seagrass rhizosphere and rhizoplane samples supplemented with neither nitrate nor glucose. Single experimental values ( $\boldsymbol{\square})$ and mean values $(\square)$ of duplicate experiments with range are shown. THRS, Thalassia hemprichii rhizosphere; THRP, Thalassia hemprichii rhizoplane; HURS, Halodule uninervis rhizosphere; HURP, Halodule uninervis rhizoplane.

A majority of the rhizosphere and rhizoplane samples exhibited detectable levels of denitrifying activity under both aerobic and anaerobic conditions ( 25 out of 31 aerobic samples and 26 out of 29 anaerobic samples). The average denitrification rates were greater under aerobic, rather than anaerobic, conditions for the samples of T. hemprichii rhizosphere (0.7:0.4), T. hemprichii rhizoplane (0.8:0.5), H. uninervis rhizosphere 
(1.0:0.7) and H. uninervis rhizoplane (1.2:1.0). It implies that some denitrifying bacteria capable of aerobic denitrification may predominate over the other denitrifiers in the rhizosphere. Although bacterial denitrification has long been believed to require completely anoxic conditions, several denitrifying species have been reported to conduct not only anaerobic, but also aerobic denitrification (Robertson and Kuenen, 1983; Bonin and Gilewicz, 1991; Patureau et al., 1994). Alternatively, the denitrifying activity detected from the aerobically incubated rhizosphere and rhizoplane samples might originate primarily from anaerobic denitrification occurring in the oxygen-depleted microzones; oxygen-depleted microzones can be created on the surface or inside the macroscopically aerobic environments (Paerl and Prufert, 1987; Paerl and Carlton, 1988).

Adding either $\mathrm{NO}_{3}^{-}$or glucose to the rhizosphere and rhizoplane samples tended to stimulate the denitrifying activity (Figs. 2 and 3). The stimulatory effect was more evident when $\mathrm{NO}_{3}^{-}$and glucose were simultaneously added (Fig. 4). Insufficiency of organic matter or $\mathrm{NO}_{3}^{-}$in the rhizosphere would be apt to restrict the magnitude of in situ denitrification.

Denitrifying activity was not found in any of the seawater samples ( 0 out of 46$)$ even supplemented with $\mathrm{NO}_{3}^{-}$and glucose, nor in any of the nonrhizosphere sediment samples supplemented with neither $\mathrm{NO}_{3}^{-}$nor glucose (0 out of 20). It, however, was detectable $\left(0.3-1.0 \mu \mathrm{mol} \mathrm{N}_{2} \mathrm{O} \cdot \mathrm{g}\right.$ wet $\left.\mathrm{wt}^{-1} \cdot \mathrm{h}^{-1}\right)$ in a rather small proportion of the nonrhizosphere sediment samples, if supplemented with $\mathrm{NO}_{3}^{-}$(2 out of 20), glucose (1 out of 20), or both (2 out of 16). Denitrifying bacteria distributed in the samples were probably insufficient in number to show significant denitrifying activity or they could just be mostly inactive.

\subsection{Bacterial enumeration}

The MPN counting values of the denitrifying bacteria in the rhizosphere and rhizoplane samples $\left(10^{2}\right.$ to $10^{4}$ cells $\cdot \mathrm{g}$ wet wt ${ }^{-1} ; 10^{3}$ to $10^{4}$ cells $\cdot \mathrm{g}$ wet wt ${ }^{-1}$ in 29 out of 32 counted values) were significantly greater than those in samples of nonrhizosphere sediment $\left(<10^{2}\right.$ to $10^{3}$ cells $\cdot \mathrm{g}$ wet $\mathrm{wt}^{-1} ;<10^{3}$ cells $\cdot \mathrm{g}$ wet $\mathrm{wt}^{-1}$ in 7 out of 10 counted values) and seawater $\left(<10^{1}\right.$ cells $\left.\cdot \mathrm{ml}^{-1}\right)$, in almost all cases. The above values might not have reflected the actual in situ density of these bacteria but would be sufficient to indicate a denser distribution of denitrifiers in the rhizosphere rather than in the outside nonrhizosphere region. The MPN counting values of heterotrophic bacteria were $10^{5}$ to $10^{6}$ cells $\cdot \mathrm{g}$ wet $\mathrm{wt}^{-1}$ for rhizosphere, rhizoplane and nonrhizosphere samples and were $10^{2}$ to $10^{3}$ cells $\cdot \mathrm{ml}^{-1}$ for seawater samples. Our data showed that the denitrifiers generally accounted for $0.1-1 \%$ of the heterotrophic bacteria in these samples.

\subsection{Characterization and grouping of denitrifying isolates}

Eighty-five strains of denitrifying bacteria were isolated from the MPN tubes capable of gas production during bacterial counts (55 strains from rhizosphere and rhizoplane samples and 30 strains from nonrhizosphere and seawater samples). All the isolates in almost all cases produced $\mathrm{N}_{2} \mathrm{O}$ in PYN broth medium under both aerobic and anaerobic 

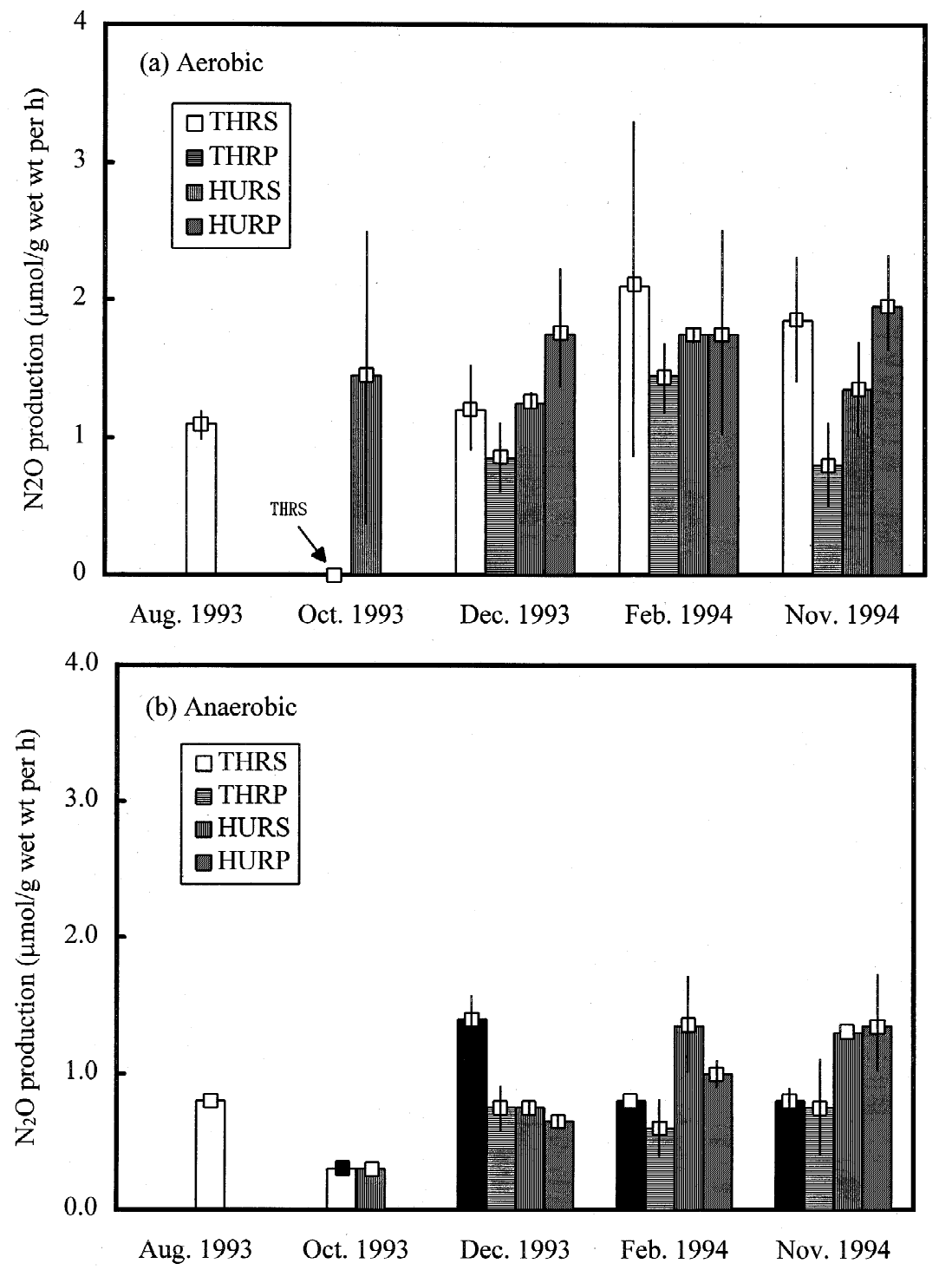

Fig. 2. Denitrification by the seagrass rhizosphere and rhizoplane samples supplemented with nitrate. Single experimental value ( $\mathbf{\square})$ and mean values $(\square)$ of duplicate experiments with range are shown. THRS, Thalassia hemprichii rhizosphere; THRP, Thalassia hemprichii rhizoplane; HURS, Halodule uninervis rhizosphere; HURP, Halodule uninervis rhizoplane.

conditions when measured by the acetylene blockage technique. $\mathrm{N}_{2} \mathrm{O}$-producing rates, however, were commonly more rapid under aerobic conditions (data not shown). The present aerobic cultures possibly could not exclude the occurrence of oxygen-depleted microenvironments since they were incubated statically in tubes. Therefore, the results 

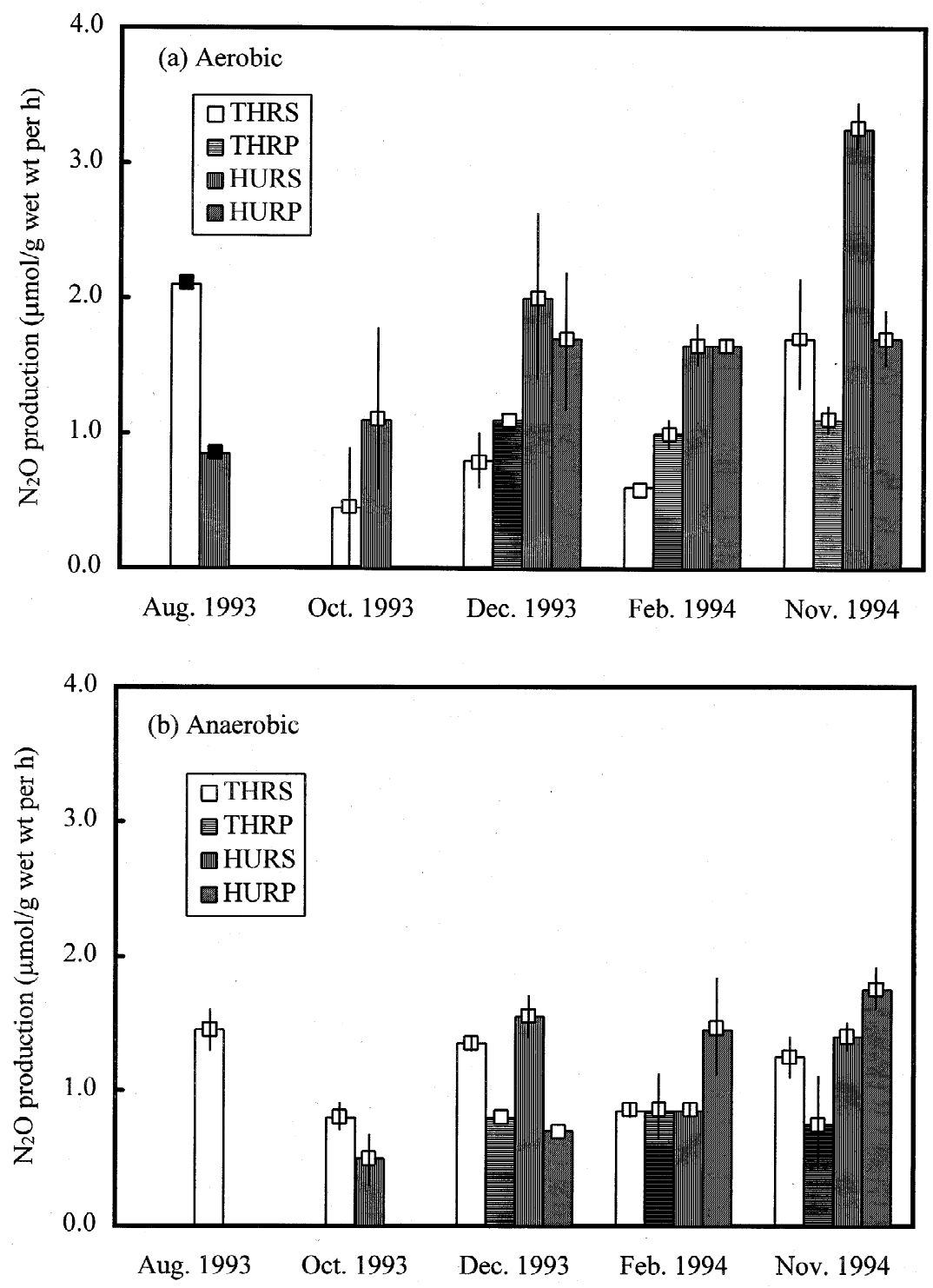

Fig. 3. Denitrification by the seagrass rhizosphere and rhizoplane samples supplemented with glucose. Single experimental values ( $\mathbf{0})$ and mean values $(\square)$ of duplicate experiments with range are shown. THRS, Thalassia hemprichii rhizosphere; THRP, Thalassia hemprichii rhizoplane; HURS, Halodule uninervis rhizosphere; HURP, Halodule uninervis rhizoplane.

obtained here did not conclusively support the above mentioned inference that denitrifying bacteria capable of aerobic denitrification predominated over the other denitrifiers in the seagrass rhizosphere. More than half of the isolates (59\%; 50 out of 85 strains) lost the denitrifying $\left(\mathrm{N}_{2} \mathrm{O}\right.$-producing) ability after subsequent laboratory 

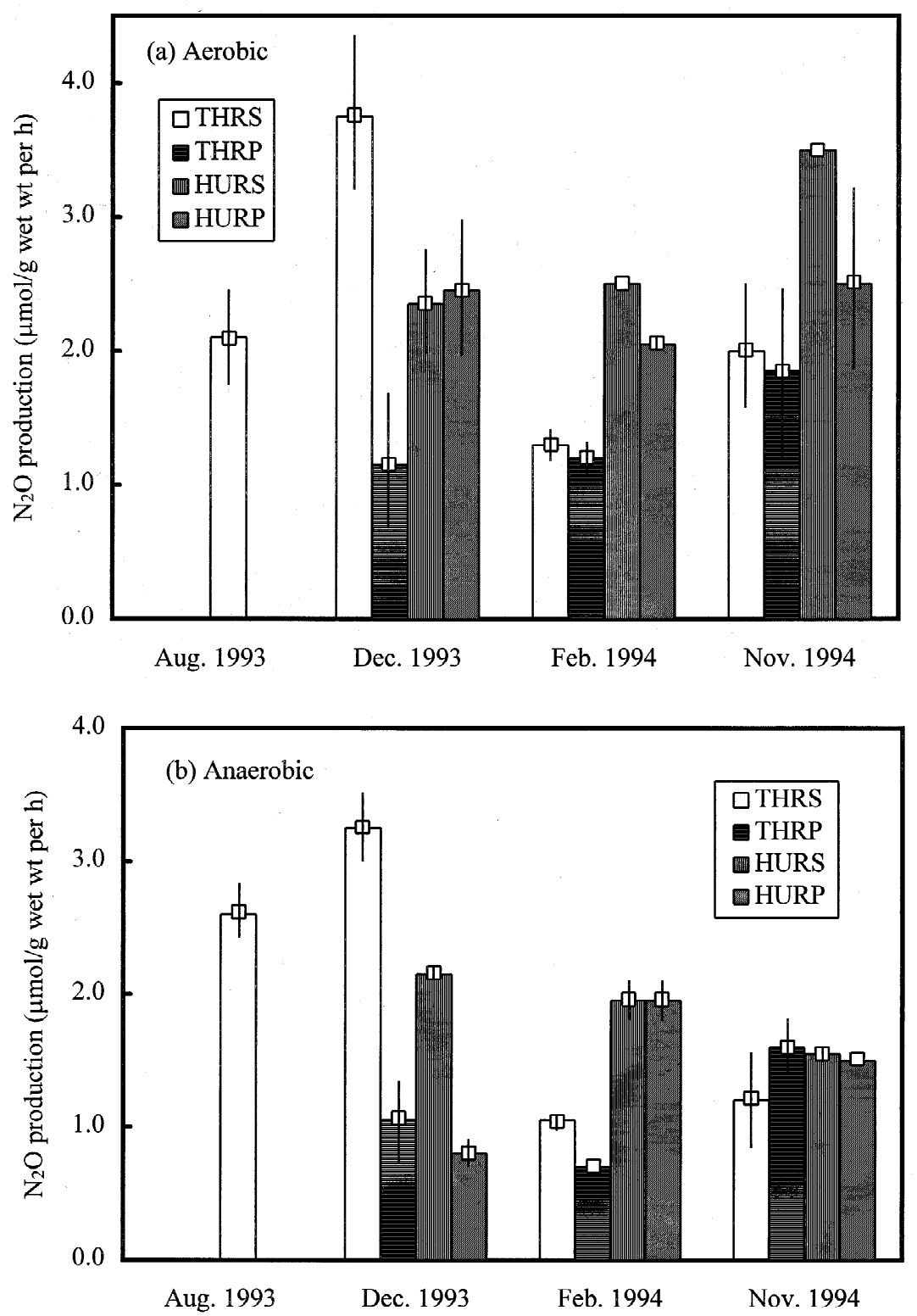

Fig. 4. Denitrification by the seagrass rhizosphere and rhizoplane samples supplemented with both nitrate and glucose. Mean values ( $\square$ ) of duplicate experiments with range are shown. THRS, Thalassia hemprichii rhizosphere; THRP, Thalassia hemprichii rhizoplane; HURS, Halodule uninervis rhizosphere; HURP, Halodule uninervis rhizoplane. 
subculture, which suggested that the in situ flora of denitrifying bacteria in the seagrass bed might be mainly composed of such denitrifiers. Denitrifying bacteria easily losing their denitrifying ability after subculture has been found to be a common phenomenon (Gamble et al., 1977). The denitrification genes that could have been lost were possibly located on the plasmid(s) as plasmid-mediated bacterial characteristics are frequently lost easily (Gamble et al., 1977).

Only the 35 denitrifying isolates (24 strains from rhizosphere and rhizoplane samples and 11 strains from nonrhizosphere sediment and seawater samples), which did not lose their $\mathrm{N}_{2} \mathrm{O}$-producing ability after subculture, were used for characterization tests. All the test isolates were rod-shaped, mostly motile (32/35), slightly to moderately halophilic (24/35) and generally Gram-negative (31/35). They were divided into seven groups, mainly based on the following tests' results: Gram stain, glucose fermentation, requirement of $\mathrm{NaCl}$ for growth, motility, flagellar arrangement and production of yellow or orange colonies on agar plates (Table 1). Groups I and II included more than half $(54 \%, 19$ out of 35 strains) of the test denitrifying isolates. Both groups included strains that were motile, nonfermentative, Gram-negative rods possessing one to several polar flagella, but only the strains of group I required $\mathrm{NaCl}$ for growth. Strains of group I were all negative for DNAse and gelatinase activities but reactions on the tests were

Table 1

Characteristics of denitrifying isolates

\begin{tabular}{|c|c|c|c|c|c|c|c|}
\hline \multirow[t]{2}{*}{ Characteristic } & \multicolumn{7}{|c|}{ Bacterial group and strain number included } \\
\hline & $\mathrm{I}(14)$ & II (5) & III (3) & IV (1) & $\mathrm{V}(1)$ & VI (7) & VII (4) \\
\hline Rod-shaped cells & $+{ }^{a}$ & + & + & + & + & + & + \\
\hline Gram stain & - & - & - & - & - & - & + \\
\hline Glucose fermentation & - & - & - & - & - & + & - \\
\hline Motility & + & + & + & - & - & + & $\mathrm{v}$ \\
\hline Polar flagellation & + & + & - & - & - & $\mathrm{v}$ & - \\
\hline Peritrichous flagellation & - & - & + & - & - & $\mathrm{v}$ & $\mathrm{v}$ \\
\hline Yellow or orange colonies & - & $\mathrm{v}$ & - & - & + & $\mathrm{v}$ & $\mathrm{v}$ \\
\hline Swarming & $\mathrm{v}$ & - & - & - & + & $\mathrm{v}$ & - \\
\hline Agarase & - & - & - & - & - & - & - \\
\hline Oxidase & $\mathrm{v}$ & + & + & + & + & + & $\mathrm{v}$ \\
\hline Catalase & + & + & + & + & + & + & + \\
\hline DNAse & - & $\mathrm{v}$ & - & - & - & $\mathrm{v}$ & - \\
\hline Gelatinase & - & $\mathrm{v}$ & - & - & + & $\mathrm{v}$ & - \\
\hline \multicolumn{8}{|l|}{ Growth in: } \\
\hline $0 \% \mathrm{NaCl}$ & - & + & + & - & - & - & $\mathrm{v}$ \\
\hline $3-6 \% \mathrm{NaCl}$ & + & + & + & + & + & + & + \\
\hline $8 \% \mathrm{NaCl}$ & $\mathrm{v}$ & $\mathrm{v}$ & + & - & - & + & $\mathrm{v}$ \\
\hline $10 \% \mathrm{NaCl}$ & $\mathrm{v}$ & $\mathrm{v}$ & + & - & - & + & $\mathrm{v}$ \\
\hline \multicolumn{8}{|l|}{ Growth at: } \\
\hline $5^{\circ} \mathrm{C}$ & $\mathrm{v}$ & $\mathrm{v}$ & + & - & - & - & $\mathrm{v}$ \\
\hline $20^{\circ} \mathrm{C}$ & + & + & + & + & + & + & + \\
\hline $35^{\circ} \mathrm{C}$ & + & + & + & + & + & + & + \\
\hline $43^{\circ} \mathrm{C}$ & $\mathrm{v}$ & $\mathrm{v}$ & $\mathrm{v}$ & - & - & - & $\mathrm{v}$ \\
\hline
\end{tabular}

a + , positive; - , negative; $v$, variable. 
variable among the strains of group II (Table 1). All the strains included in the two groups could be identified as belonging to the genus Pseudomonas which has been reported to include the most common denitrifying bacteria found in the soil or aquatic sediments. Group III, similar to group II, consisted of motile, nonfermentative, Gramnegative rods able to grow in the absence of $\mathrm{NaCl}$. All the strains included in this group, however, achieved motility by means of peritrichous but not polar flagella. They were identified as members of the genus Alcaligenes. Both of the isolates included in groups IV and V, respectively, were nonmotile, nonfermentative, and Gram-negative rods, but only the isolate included in group IV produced swarming, yellow-pigmented colonies on PY-II agar plates. The isolate of the group IV might be a Cytophaga sp. but that of the group V was possibly a species of the genus Moraxella. The five strains in group VI were motile, fermentative, and Gram-negative rods with requirement of $\mathrm{NaCl}$ for growth. They could be assigned to the genus Vibrio or Photobacterium. Halophilic, facultatively anaerobic, fermentative bacteria comprise a predominant bacterial group in many marine habitats. Only few of these, however, have been previously found to be capable of denitrification (Shieh and Liu, 1996). Four Gram-positive strains in the group VII have not been identified to the generic level.

This study demonstrated active potential rates of bacterial denitrification in the rhizosphere and rhizoplane of the seagrasses $T$. hemprichii and $H$. uninervis. Such potential rates of denitrification were generally far greater than those detected from various nonrhizosphere sediments of diverse sources reported elsewhere (Seitzinger, 1988). To what extent these data have reflected the in situ rates of denitrification, however, requires further study.

\section{Acknowledgements}

This work was supported by a grant NSC83-0209-B-002A-010 from the National Science Council. The authors would like to thank Dr. J.-S. Chen for advice and Mr. W.D. Jean for assistance in preparing the manuscript.

\section{References}

Balderston, W.L., Sherr, B., Payne, W.J., 1976. Blockage by acetylene of nitrous oxide reduction in Pseudomonas perfectomarinus. Appl. Environ. Microbiol. 31, 504-508.

Bonin, P., Gilewicz, M., 1991. A direct demonstration of "co-respiration" of oxygen and nitrogen oxides by Pseudomonas nautica: some spectral and kinetic properties of the respiratory components. FEMS Microbiol. Lett. 80, 183-188.

den Hartog, C., 1970. The Seagrasses of the World. North-Holland, Amsterdam.

Gamble, T.N., Betlach, M.R., Tiedje, J.M., 1977. Numerically dominant denitrifying bacteria from world soil. Appl. Environ. Microbiol. 33, 926-939.

Iizumi, H., Hattori, A., McRoy, C.P., 1980. Nitrate and nitrite in interstitial waters of eelgrass beds in relation to the rhizosphere. J. Exp. Mar. Biol. Ecol. 47, 191-201.

Knowles, R., 1982. Denitrification. Microbiol. Rev. 46, 43-70. 
Kuo, J., McComb, A.J., 1989. Seagrass taxonomy, structure and development. In: Larkum, A.W.D., McComb, A.J., Shepherd, S.A. (Eds.), Biology of Seagrasses: a Treatise on Biology of Seagrasses with special reference to the Australian Region. Elsevier Science, Amsterdam, pp. 6-73.

Moriarty, D.J.W., Boon, P.I., 1989. Interactions of seagrasses with sediment and water. In: Larkum, A.W.D., McComb, A.J., Shepherd, S.A. (Eds.), Biology of Seagrasses: a Treatise on Biology of Seagrasses with special reference to the Australian Region. Elsevier Science, Amsterdam, pp. 500-535.

Nybakken, J.W., 1993. Marine biology: an Ecological Approach, third ed. Harper Collins, New York.

Paerl, H.W., Prufert, L.E., 1987. Oxygen-poor microzones as potential sites of microbial $\mathrm{N}_{2}$ fixation in nitrogen-depleted aerobic marine waters. Appl. Environ. Microbiol. 53, 1078-1087.

Paerl, H.W., Carlton, R.G., 1988. Control of nitrogen fixation by oxygen depletion in surface-associated microzones. Nature 332, 260-262.

Patureau, D., Davison, J., Bernet, N., Moletta, R., 1994. Denitrification under various aeration conditions in Comamonas sp., strain SGLY2. FEMS Microbiol. Ecol. 14, 71-78.

Robertson, L.A., Kuenen, J.G., 1983. Thiosphaera pantotropha gen. nov. sp. nov., a facultatively anaerobic, facultatively autotrophic sulphur bacterium. Microbiology 129, 2847-2855.

Seitzinger, S.P., 1988. Denitrification in freshwater and coastal marine ecosystems: Ecological and geochemical significance. Limnol. Oceanogr. 33, 702-724.

Shieh, W.Y., Liu, C.M., 1996. Denitrification by a novel halophilic fermentative bacterium. Can. J. Microbiol. 42, 507-514.

Shieh, W.Y., Simidu, U., Maruyama, Y., 1988. Nitrogen fixation by marine agar-degrading bacteria. J. Gen. Microbiol. (retitled Microbiology from 1994) 134, 1821-1825.

Shieh, W.Y., Simidu, U., Maruyama, Y., 1989. Enumeration and characterization of nitrogen-fixing bacteria in an eelgrass (Zostera marina) bed. Microb. Ecol. 18, 249-259.

Smith, R.D., Dennison, W.C., Alberte, R.S., 1984. Role of seagrass photosynthesis in root aerobic processes. Plant Physiol. 74, 1055-1058.

Sorensen, J., 1978. Denitrification rates in marine sediment as measured by the acetylene inhibition technique. Appl. Environ. Microbiol. 36, 139-143.

van Rattle, C.D., Patriquin, D.G., 1979. Use of "acetylene blockage" technique for assaying denitrification in a salt marsh. Mar. Biol. 52, 315-320.

Yoshinari, T., Hynes, R., Knowles, R., 1977. Acetylene inhibition of nitrous oxide reduction and measurement of denitrification and nitrogen fixation in soil. Soil Biol. Biochem. 9, 177-183. 